\title{
MINERAL RESOURCE POTENTIAL OF THE GRANITE CHIEF WILDERNESS STUDY AREA, PLACER COUNTY, CALIFORNIA
}

\author{
SUMMARY REPORT
}

By

David S. Harwood

U.S. Geological Survey

and

Francis E. Federspiel, Eric E. Cather, and Douglas F. Scott

U.S. Bureau of Mines

\section{STUDIES RELATED TO WILDERNESS}

Under the provisions of the Wilderness Act (Public Law 88-577, September 3, 1964) and the Joint Conference Report on Senate Bill 4, 88th Congress, the U.S. Geological Survey and the U.S. Bureau of Mines have been conducting mineral surveys of wilderness and primitive areas. Areas officially designated as "wilderness," "wild," or "canoe" when the act was passed were incorporated into the National Wilderness Preservation System, and some of them are presently being studied. The act provided that areas under consideration for wilderness designation should be studied for suitability for incorporation into the Wilderness System. The mineral surveys constitute one aspect of the suitability studies. The act directs that the results of such surveys are to be made available to the public and be submitted to the President and the Congress. This report discusses the results of a mineral survey of the Granite Chief Wilderness Study Area, Tahoe National Forest, Placer County, California. The area was classified as a further planning area (A5-261) during the Second Roadless Area Review and Evaluation (RARE II) by the U.S. Forest Service, January 1979.

\section{SUMMARY}

A mineral resource survey of the Granite Chief Wilderness Study Area in the Tahoe National Forest and Lake Tahoe Management Area was conducted between 1979 and 1981. The mineral resource potential of the area was evaluated from geologic and geochemical studies by the U.S. Geological Survey, and from the examination of existing published and unpublished records of mining prospects and field examination of prospects, mineralized rocks, and placer deposits by the U.S. Bureau of Mines.

These investigations indicate that the study area has a low potential for mineral resources. Analyses of samples taken from prospect pits, altered outcrops, and stream-sediment samples indicate no minable quantities of precious or base metals. Placer deposits are too small and too low in grade to be considered a resource.

Substantial deposits of sand, gravel, and glacial till suitable for construction materials occur within the area, but their inaccessibility and remoteness from major markets preclude their being classified as a resource. No potential for oil, gas, coal, or geothermal resources was identified.

\section{INTRODUCTION}

\section{Location and access}

The east boundary of the study area approximately follows the crest of the Sierra Nevada from a point near Anderson Peak, about $5 \mathrm{mi}(8 \mathrm{~km})$ south of Donner Pass, southward to Twin Peaks, a distance of about $13 \mathrm{mi}(20 \mathrm{~km})$. The area extends down the western slope of the range about 7 $\mathrm{mi}(12 \mathrm{~km})$ at its widest point and encompasses about 23,400 acres $(9470 \mathrm{ha})\left(57 \mathrm{mi}^{2}\right)$. At its nearest point, the east boundary of the study area lies only $6 \mathrm{mi}(9 \mathrm{~km})$ west of Tahoe City, Calif., a major four-season recreational center located on the northwest shore of Lake Tahoe (fig. 1).

State Highway 89 follows the Truckee River between Tahoe City and Truckee, Calif., and lies 3 to $6 \mathrm{mi}(5$ to $9 \mathrm{~km}$ ) east of the study area. Several secondary roads spur off from State Highway 89 and extend westward nearly to the eastern and southern parts of the study area. A number of hiking trails head on these secondary roads and extend into the study area. A 16-mile segment of the Pacific Crest Trail lies within the area and generally parallels its east boundary.
Access to the western part of the study area is provided by a paved secondary road that extends from Foresthill, Calif., and follows the course of the Middle Fork of the American River eastward to Talbot campground (fig. 1), one of several recreational facilities provided and maintained by the U.S. Forest Service in the area of French Meadow Reservoir. From French Meadow Reservoir several graded gravel roads extend eastward to the west border of the study area. Several trails head on these gravel roads and provide hiking access to the study area from the west. Much of the study area is designated as a California Wildlife Preserve.

\section{Present and previous studies}

Early geologic work on the bedrock in the area was done by Lindgren (1897) as part of his study of the Truckee quadrangle. More recently, Birkeland $(1961,1963)$ mapped the Quaternary glacial and volcanic deposits along the eastern margin of the study area as part of his study of the late Cenozoic history of the Truckee-Tahoe area. Hudson (1951) mapped the geology north of the study area near Donner Pass. Geologic studies, related specifically to evaluating the mineral resource potential of the study area, were conducted by the U.S. Geological Survey in 1980 and 1981. Bedrock and 
surficial glacial deposits were examined for concentrations of economic minerals and materials and a detailed geologic map of this part of the Sierra Nevada resulted from these studies (Harwood, 1981). Stream-sediment samples, collected during the geologic mapping, provided data for evaluating potential economic concentrations of metals that might have gone undetected during the mapping. An analysis of this streamsediment data is given by Harwood (1982a).

During 1979 and 1980, the U.S. Bureau of Mines examined their published literature as well as unpublished records of Placer County, the U.S. Bureau of Land Management, and the U.S. Forest Service to determine mining claims and lease locations. During this time, fieldwork was conducted to find and sample possible claimed areas, prospect workings, and mineralized areas within and immediately adjacent to the study area. The field search was greatly aided by the use of a helicopter, but because of the rugged terrain and locally dense vegetation, some minor workings may not have been found. In spite of these difficulties, 18 lode and 58 placer samples from areas with suspected mineral values were collected and analyzed. Lode samples were crushed, mixed, split, and fire-assayed for gold and silver. The presence of other suspected metallic elements was checked by atomic-absorption, colorimetric, or Xray fluorescence techniques. In addition, most samples were analyzed for $\mathbf{4 0}$ elements by standard semiquantitative spectrographic methods. Placer samples were concentrated in the field by panning. Field samples were further concentrated in the laboratory on a Wilfley table; visible gold was picked out of these concentrates and selected samples were amalgamated. Gold content was determined by weighing the hand-picked particles plus the amalgamated gold.

\section{GEOLOGY AND GEOCHEMISTRY PERTAINING TO MINERAL RESOURCE ASSESSMENT}

\section{Geology}

\section{Geologic setting}

The Granite Chief Wilderness Study Area is located in the northern part of the Sierra Nevada, a faulted and westward-tilted range that extends nearly the length of eastern California. The eastern flank of the Sierra Nevada is precipitous and the steep topography is controlled by a major normal fault system showing east-side-down displacement immediately east of the study area. The western slope of the range, which is not as steep as the eastern escarpment, is deeply incised by major river systems that drain westward to the Great Valley of California. The North Fork and Middle Fork of the American River rise in the study area and expose a wide variety of rocks in their glacially scoured canyons. Tertiary volcanic rocks cap the interfluves between the major rivers in this part of the western slope of the range and Tertiary and Quaternary volcanic rocks compose most of the bedrock exposed east of the range-front fault system in the Tahoe-Truckee area. Unconsolidated glacial deposits, which mark the margins and ends of Pleistocene alpine glaciers, occur along most of the major drainages in the area.

\section{Metamorphic rocks}

The oldest rocks in the study area are highly deformed quartzite, calcareous quartzite, and slate that contain minor amounts of metamorphosed chert and dolomitic marble, all of which are mapped as the Shoo Fly Formation. ${ }^{1}$ Along Five Lakes Creek, the Shoo Fly Formation is unconformably overlain by metamorphosed submarine pyroclastic rocks that are correlated with the Upper Devonian Sierra Buttes Formation (Harwood, 1982b). The exact age of the Shoo Fly Formation is unknown, but it can be no younger than Late Devonian; the age of the overlying Sierra Buttes Formation.

This belt of rocks, assigned to the Shoo Fly Formation and the Sierra Buttes Formation, lies on the east limb of a major synclinorium. A thin unit of Triassic limestone, Jurassic volcaniclastic rocks of the Sailor Canyon Formation, and unnamed mafic pyroclastic and intrusive rocks of probable Jurassic age lie in the core of the synclinorium west of the study area. Farther west, east-dipping belts of the Shoo Fly Formation and late Paleozoic volcanic rocks, including the Sierra Buttes Formation, define the west limb of the synclinorium.

On the west limb of the synclinorium, the Shoo Fly Formation contains a broad and extensive zone of goldbearing quartz veins that define the classic Mother Lode belt of the Sierra Nevada. The mineral resource potential of the Mother Lode belt located west of the Granite Chief area has been evaluated by Harwood and others (1982) in their study of the North Fork of the American River Wilderness Study Area.

Despite the fact that the same host rocks of the Mother Lode belt, specifically the Shoo Fly Formation, occur within the Granite Chief area, the Shoo Fly Formation here does not contain significant quartz veins or major zones of alteration and mineralization. If the gold-bearing quartz veins of the Mother Lode belt represent remobilized constituents of the Shoo Fly host rocks, we can only assume that the process did not occur in the Shoo Fly Formation of the Granite Chief area or that the mobilized material was redeposited in part of the host rocks that have been removed by erosion. Analyses of the Shoo Fly Formation in and adjacent to the Granite Chief Wilderness Study Area indicate only scattered traces of gold, silver, and tungsten.

\section{Intrusive rocks}

The metamorphic rocks are intruded by large tracts of medium-grained, locally porphyritic hornblende granodiorite of the Sierra Nevada batholith. No significant mineral resources were found in the granodiorite or related granitic rocks in the study area.

\section{Tertiary voleanic rocks}

The metamorphic country rocks and plutonic rocks of the Sierra Nevada batholith are unconformably capped by a variety of Tertiary volcanic rocks in and adjacent to the Granite Chief area. The lowest unit in the Tertiary volcanic sequence consists of rhyolite tuff of Oligocene age (Dalrymple, 1964), and most of the overlying rocks are andesitic lahar deposits of Miocene and Pliocene(?) age. Pleistocene volcanic rocks occur east of the study area (Birkeland, 1963; Dalrymple, 1964). No mineralized areas were found in the Tertiary or Quaternary volcanic rocks in or adjacent to the study area.

On the western slope of the Sierra Nevada, goldbearing gravels locally underlie the rhyolitic tuff that occurs at the base of the Tertiary volcanic section. The volume of auriferous gravel in these paleochannel deposits increases westward down the flank of the range, and significant amounts of gold were produced from the western reaches of these channel deposits in the latter half of the 19th century (Lindgren, 1911). No gravel deposits were found beneath the rhyolite tuffs or within the overlying Tertiary volcanic sequence in the Granite Chief area.

Several small volcanic vents, which represent conduits for at least part of the Tertiary volcanic rocks, were mapped along a northwest-trending zone parallel to the eastern range-front fault system located east of the study area. Granitic rocks of the Sierra Nevada batholith are locally bleached and altered to a friable grus along this zone of 
faulting and volcanic intrusion. No mineralization was detected in the altered granite or in the volcanic vent rocks.

\section{Quaternary glacial deposits}

Unconsolidated glacial deposits, consisting predominantly of bouldery till, occur in and along the margins of most of the drainages within and east of the study area. These deposits represent marginal and terminal moraines of local glaciers that repeatedly capped this part of the Sierra Nevada during the Pleistocene. Material within the glacial deposits was derived from the local bedrock. The glacial deposits were not analyzed directly for potential economic minerals, but these deposits contribute to the bedload of modern streams and that material was analyzed in the geochemical sampling program. The material within the glacial deposits, particularly those located east of the study area, has been used locally for road metal and subgrade fill, but the potential for widespread use of this material is small.

\section{Geochemistry}

The results of a geochemical study of panned concentrates from stream-sediment samples within the study area (Harwood, 1982a) and comparable investigations by the U.S. Bureau of Mines failed to identify any potentially favorable mineralized areas. The geochemical studies, however, did locate sporadic traces of gold in widely scattered streamsediment samples from drainages underlain by the Shoo Fly Formation. Gold values identified in original studies could not be duplicated in subsequent sampling (see Harwood, 1982a) and it is concluded that gold within the Shoo Fly Formation in this area occurs in widely disseminated, trace amounts and does not constitute a resource.

\section{PROSPECTS AND MINERALIZED AREAS}

Gold and silver have been the principal interest of prospectors in the region since the California gold rush in 1849. Most production has come from placer and drift mining $20 \mathrm{mi}(32 \mathrm{~km})$ west of the study area, but lode deposits in quartzite, slate, and metavolcanic rocks have also yielded significant amounts of gold and silver. About 3 to $5 \mathrm{mi} \mathrm{(5} \mathrm{to}$ $8 \mathrm{~km}$ ) west of the study area, small amounts of gold have been produced from quartz veins in calcareous sedimentary rocks and altered andesite.

An inactive tungsten prospect lies $1 \mathrm{mi}(1.6 \mathrm{~km})$ southwest of the study area in a scarn zone lying along the contact between calcareous metasedimentary rocks of the Shoo Fly Formation and granodiorite. The property is developed by a caved shaft estimated to have been $50 \mathrm{ft}(15 \mathrm{~m})$ deep. No record of production could be found.

No mining activity is currently being conducted in the study area and no resources could be identified. In spite of the thorough prospecting that must have taken place in the Granite Chief area as a result of its proximity to the Mother Lode and Comstock discoveries, no record of mining claims or mineral production could be found. A few small pits are the only evidence of prospecting activity. Outcrops with quartz veins, pegmatite dikes, and rusty-weathering alteration were examined and sampled; results indicate only minor amounts of gold and silver.

The sporadic occurrence of minor quartz veins indicates at least limited hydrothermal action or remobilization of host-rock material in the study area. These veins occupy northwest-trending fracture zones in granitic and metamorphic rocks and locally carry as much as three percent pyrite.

Gravel, which occurs in all the major valleys in the area, is primarily of glaciofluvial origin. Some reworking of glacial deposits by modern streams has produced small bars and benches that contain sporadically distributed minor amounts of gold.

\section{ASSESSMENT OF MINERAL RESOURCE POTENTIAL}

Investigations by the U.S. Bureau of Mines and the U.S. Geological Survey indicate the study area has low mineral resource potential. Although the area is underlain by rocks that have hosted deposits of gold, silver, and tungsten in the surrounding region, no similar deposits have been found in the study area. Lode samples taken during this study from the few small workings and seemingly favorable altered outcrops contain only minor amounts of gold and silver. Geochemical analyses of stream-sediment samples also indicate only scattered minor amounts of gold and silver.

Two samples from a 1,000 - by $300-\mathrm{ft}$ (300- by $90-\mathrm{m})$ outcrop of dolomitic limestone average less than 50 percent $\mathrm{CaO}$. One sample contains about 10 percent $\mathrm{MgO}$, making it unlikely that the limestone could meet the American Society for Testing Materials specification for $\mathrm{MgO}$ in portland cements.

Most of the placer samples taken from potentially favorable localities in the major drainages of the study area contain little or no gold values. Two samples from Five Lakes Creek contain gold values of 122 and 227 cents/yd (159 and 195 cents $/ \mathrm{m}^{3}$ ), assuming $\$ 500 /$ troy oz as a price of gold. These samples are from small volumes of gravel that are not considered a resource.

Although substantial volumes of sand and gravel occur in the area, the deposits are too far from major markets to be considered a resource.

The area has no potential for oil, gas, or coal resources.

\section{REFERENCES CTTED}

Birkeland, P. W., 1961, Pleistocene history of the Truckee area, north of Lake Tahoe, California: Stanford, California, Stanford University, Ph.D. thesis, 126 p.

1963, Pleistocene volcanism and deformation of the Truckee area, north of Lake Tahoe, California: Geological Society of America Bulletin, v. 74, no. 12, p. 1453-1464.

Dalrymple, G. B., 1964, Cenozoic chronology of the Sierra Nevada of California: California University Publications in Geological Sciences, v. 47, 40 p.

Harwood, D. S., 1981, Geologic map of the Granite Chief Wilderness Study Area and adjacent part of the Sierra Nevada, California: U.S. Geological Survey Miscellaneous Field Studies Map MF-1273-A, scale $1: 62,500$.

1982a, Geochemical maps of the Granite Chief Wilderness Study Area, California: U.S. Geological Survey Miscellaneous Field Studies Map MF-1273-B, scale $1: 95,000$.

- 1982b, Stratigraphy of upper Paleozoic volcanic rocks and regional unconformities in part of the northern Sierra terrane, California: Geological Society of America Bulletin, [in press] .

Harwood, D. S., Griscom, Andrew, Federspiel, F. E. Leszcykowski, A. M., and Spicker, F. A., 1982, Mineral resource potential map of the North Fork of the American River Wilderness Study Area (RARE II No. 5-262), Placer County, California: U.S. Geological Survey Miscellaneous Field Studies Map MF-1177-C, scale 1:62,500.

Hudson, F. W., 1951, Mount Lincoln-Castle Peak area, Sierra Nevada, California: Geological Society of America Bulletin, v. 62, no. 8, p. 931-952.

Lindgren, Waldermar, 1897, Truckee, California: folio 39 of Geologic Atlas of the United States: U.S. Geological Survey, scale 1:62,500.

- 1911, The Tertiary gravels of the Sierra Nevada of California: U.S. Geological Survey Professional Paper 73,226 p. 


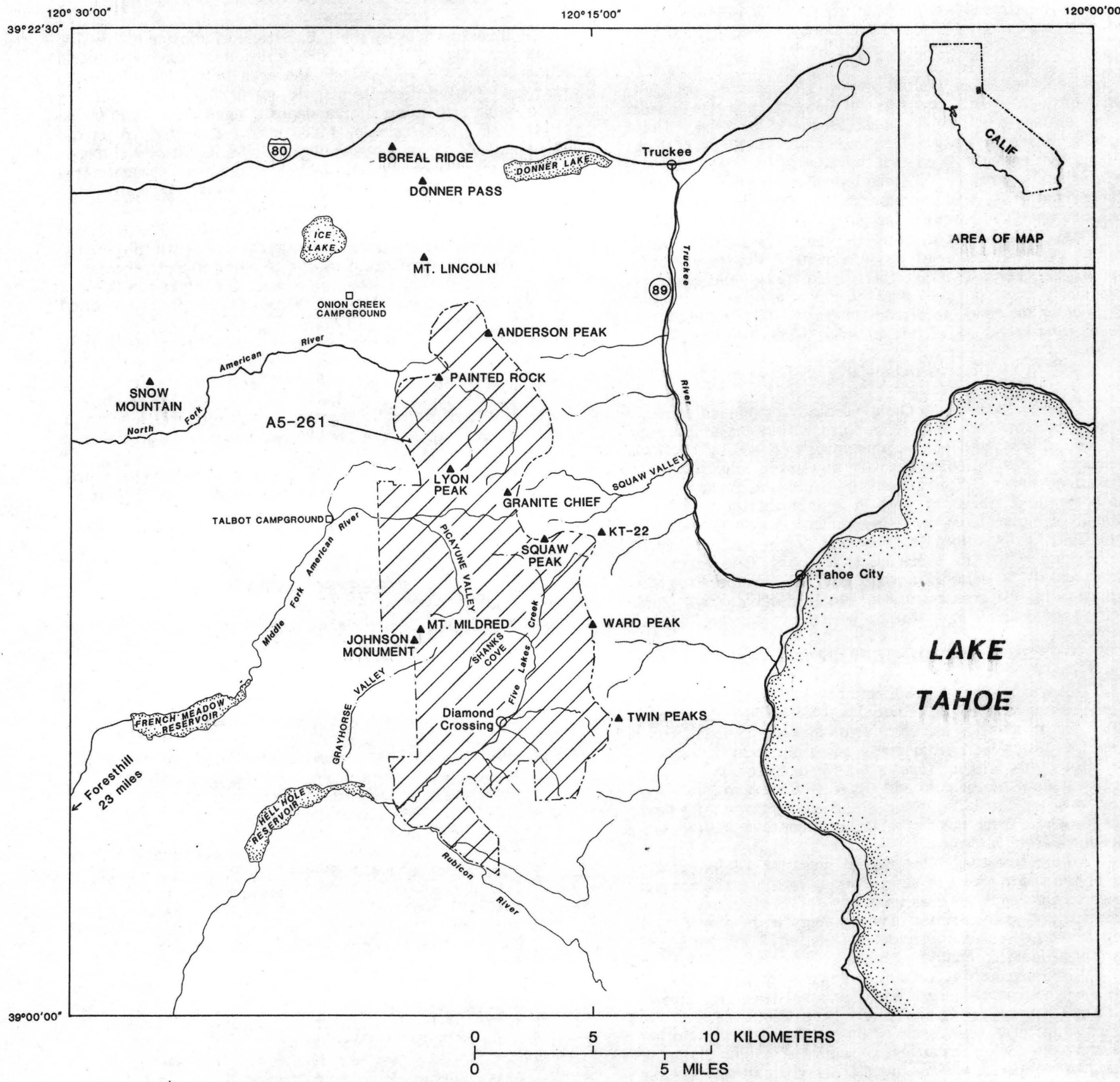

Figure 1.-Location of the Granite Chief Wilderness Study Area (A5-261). Analyses of samples taken from prospect pits, altered outcrops, and stream-sediment samples indicate no anomalous areas favorable for mineral resource potential. 